\title{
NEW APPROACHES TO THE COMMUNICATIVE STRATEGIES REALIZATION
}

\section{РЕАЛІЗАЦІЯ КОМУНІКАТИВНОЇ СТРАТЕГІЇ: НОВІ ПІДХОДИ}

\section{РЕАЛИЗАЦИЯ КОММУНИКАТИВНОЙ СТРАТЕГИИ: НОВЫЕ ПОДХОДЫ}

\section{Smyrnova 0.}

$\mathrm{PhD}$, an employee of the Institute of International Relations Taras Shevchenko National University of Kyiv, an expert in the field of emotions and non-traditional marketing. E-mail: lesia.smirnova@gmail.com

\section{Смирнова О.B.}

Кандидат політичних наук, науковий співробітник Інституту міжнародних відносин Київського національного університету імені Тараса Шевченка, спеціаліст у галузі емоцій та нетрадиційного маркетингу. E-mail: lesia.smirnova@gmail.com

\section{Смирнова Е.B.}

Кандидат политических наук, научный сотрудник Института международных отношений Киевского национального университета имени Тараса Шевченко, специалист в области эмоций и нетрадиционного маркетинга. E-mail: lesia.smirnova@gmail.com

Abstract. Information glut led to significant changes in the structure of communication in the whole and marketing, in particular. It requires absolutely new approaches to the communicative strategies realization. Per day a person gets thousands of advertising messages. Product promotion is a new substance, like water or air. Advertising has become a background. Within the framework of behavioural psychology it means that the product, as the market becomes increasingly saturated, finds it extremely difficultto break through the filter of buyers' selective perception.The article highlights the issues of filtering through the audience selective perception which underlies a powerful informational message. The conclusion of the author is to change the approaches to the communicative strategies realization.

Keywords:neuroscience, neuromarketing, communicative strategies, neuromarketing strategies, new communicative approaches.

Анотація. Перенасичення інформаџією призвело до якісних змін у структурі комунікацій в цілому та у маркетингу зокрема, щуо потребує абсолютно нових підходів y реалізації комунікативних стратегій. За день людина отримує декілька тисяч рекламних повідомлень. Просування продукту - нова субстанція на кшталт води або повітря. Реклама стала фоном. 3 точки зору поведінкової психологї ие означає, що продукту при постійному зрості насичення ринку стає складніше пробитись крізь фільтр селективного сприйняття аудиторії. У статті висвітлюються питання відносно того, як пробитись крізь фільтр селективного сприйняття аудиторії, щяо полягає в основі сильного інформаџійного повідомлення. Висновки автора зводяться до необхідності змінювати підходи у реалізації комунікативних стратегій.

Ключові слова: нейронаука, нейромаркетинг, комунікативні стратегії, нейромаркетингові стратегії, нові комунікативні підходи.

Аннотация. Перенасыщение информацией привело к качественным изменениям 6 структуре коммуникаций в иелом и в маркетинге в частности, что требует абсолютно новых подходов в реализачии коммуникативных стратегий. За день человек 
получает несколько тысяч рекламных сообщений. Продвижение продукта - новая субстанция вроде водь или воздуха. Реклама стала фоном. С точки зрения поведенческой психологии это означает, что продукту при постоянном росте насыщения рынка становится сложнее пробиться через фильтр селективного восприятия аудитории.В статье освещзаются вопросы относительно того, как пробиться через фильтр селективного восприятия аудитории, что лежит в основе сильного информачионного сообщения. Выводы автора сводятся к необходимости менять подходы в реализации коммуникативных стратегий.

Ключевые слова: нейронаука, нейромаркетинг, коммуникативные стратегии, нейромаркетинговые стратегии, нове коммуникативные подходы.

Formulation of the problem. We live in time of fleeting pictures, the time ofinfoshock. The amount of information we receive per day is equal to the amount we received for a yearlast century. It influences all areas of our life.

For example, in order to master basic knowledge at school nowadays, the training should be extended for a few decades (in fact, we have this introduced 12- year system of education now). However, it is not the way out, because the amount of new knowledge will increase in many timesduring this period. Therefore, we need tochange our approach. Education of knowledge should turn into education of understanding.

Change of approach concerns marketing area too. Market is oversaturated with information, goods and advertising, which bringdown the buyer's interest in the product. Within the framework of behavioural psychologyit means that the product,as the market becomes increasingly saturated, finds it extremely difficult to break through the filter of buyers' selective perception. That is, the product is not perceived, is not memorized in the consciousness as potentially desirable.

Object of the article. Product Advertising has become a new substance like water or air. A person receives several thousands of advertising messages per day. Advertising has become a background. This is the reason ofso-called advertising blindness. So, the question is: how to fight the way through this wall? How to reach the audience? What is the basis of a strong advertising message? What is the way to attract people's attention to you.We need to change our approaches to marketing. Traditional marketing does not work anymore.

Analysis of the latest researches and publications. The concept of neuromarketing is very young. The psychologists of Harvard University started to develop it only in the late 90s.First research in the field of neuromarketing was made by G. Zaltman in 1999. The method created beforehand prepared images for stimulating strong emotional feedback which causes the desire to buy. Later this technique was patented as Zaltman Metaphor Elicitation Method or ZMET. The point of ZMET is to transfer true wishes of consumers from unconscious mind into conscious one with the help of metaphor-images. Such images create graphic collages which lay in the basis of commercials [Zaltman, 2003: 117].

In 2002 Al Schmidt, the professor of Erasmus University Rotterdam, made up the term of "neuromarketing".

The whole theory of neuromarketing is based on the idea that more than $90 \%$ of a person's intellectual activity, including emotions, takes place in the subconscious mind, that is lower the levels controlled by consciousness. The former idea of rational taking decisions is disproved. Daniel Kahneman, a psychologist and a Nobel economy prize winner, writes a lot about this issue in his works [Kahneman, 2011:40]. At present, conceptual foundation of neuromarketing is based on the works of G.Zaltman, A. Trandl, M.Lindstrom, D.Lewisand others $[3 ; 4 ; 5 ; 6]$.

Basic research material. So, thefirstthingwhichshouldbenoted is -If you want somebody tolearn about you - hide.

It makes no senseto inform about your existence. Everybody has already got to know about you or can learn If they want. Otherwise, you're just not interesting. The purpose of 
marketing today is to makeeverybody would like to learn about you, to find you and to get interested in you. Nowadays it's not enough to write "We are open!" How can you arise interest andattract attention, breaking the selective perception of the audience?

First of all it's necessary to focus on the product itself and its peculiarities, but not on the information about its existence. Taking into account the fact that current range of goods is extremely wide, and we have little time for making decisions, we make decisions intuitively, emotionally but not rationally. So we need to focuson the perception of the product among all the others [Kahneman, 2000: 153].

Secondly, if you want to be interesting for somebody - hide. It is, so called, 'keyhole effect.' The need for recognition and sales growth is the result of your unpopularity, in fact. Recognition does not make sense any longer. Hide yourself and make them find you.As it was in yourchildhood.

How should you do it? It's very simple. Create a boom. Make art your communication channel. Play the game. Be unobtrusive. Ask riddles. Make vapid things spicy.

Just informing about the product and its price is boring, thereforesuch marketing is not effective. It is necessary to involve and pick up the audience [Goldhaber, 2011: 67].

Marketing of information becomes marketing of participation. Today everyone wants to take photos, write, draw, design, think up by themselves. Inspire. Here it does not matter what you do, it's important how you do it. Make your audience participantsof anexciting game.

The neuroscience experts say that the game is a complex, important and necessary biological process. Within few erasthe game as a process evolves and helps to survive both animals and humans. The game forms the brain, makes it more intelligent, increases the ability to adapt. The game helps to develop empathy and creativity, promotes the formation of complex social groups [Hood, 2015: 264]. The basis of the game is pleasure, which is an important characteristic of the new marketing. There may be flashmobs, challenges, performances, whatever you like. It is the best way of delivering your message. And the process is no less important than the result in this case.

Marketing "here and now". We used to have monostandards ofunderstanding things, everything used to be submittedto logic, time used to be linear. Now we have diversity of views and understandings, emotions rule the world, andwe have doubtsconcerning the linearity of time, when we sayabout the existence of different realities. Social communication has also become different. For example,it used to be clear who your friend was and who your enemy was, but now, with the appearance of social networks, we have a new system of fastchanging, various social connections and relationships. With the understanding that in future we will not move in the same direction, we feelstressed because of uncertainty, therefore pleasure of "here and now" comes on the stage [Lanham,2006: 43].

But still,we are so interested insomething new in our future that we even begin our conversation with the question: "What's new?". As Alice in Wonderland says, "One should run as fast as one's legs will carry one in order to stay in the place". In order to be held up we constantly need something new: a new proposal, a new approach, a new game. But everything what is new today, is already old. Current and vital things are more important than new things. Staying in the moment of "here and now" brings us joy. Marketing focus changes its position to the happiness of moment. It's essential to understand that everything what we do should bring us joy in our current life. Future does not exist any more [.

Marketing of sense gives place to marketing of emotions. All Western cultures and antique philosophy praisethe beauty of the human mind. Emotions, on the contrary, have always been considered as something brute, impulsive anduninteresting for science. However, researches now state the opposite. Just emotions are a "trigger" and they determine most of our consciously made decisions [Kahneman, 2006:196]. There are many good works on this topic of Daniel Kahneman, thepsychologistwho won the Nobel Prize in Economics. 
All of our mental processes are worked up at several levels. We, initially, perceive all external irritants of the world by senses. We realize such irritants as sound, image, smell only in 200-500 milliseconds. What happens before? Before it,neural activity is observed in the most ancient part of the brain within the limbic system (the place where emotions are born). We can't intentionally influence the going on processes there until they don't reach our consciousness. From the limbic system information goes to the neocortex (awareness and other cognitive processes). So during 200-500milliseconds the picture of our vision ofthe world is created without our help [Lewis, 2016a: 123]!

Our will has theright of veto to modify or discontinue the started motion in the emotional system. But precisely emotions set in motion the flywheel and are the prime cause of a particular action. Selection and evaluation of incoming stimuli are going on exactly in the place where emotions are born. That is, a person perceives only those things which causeemotions. So rational thinking leads to conclusions, emotions lead to actions.

Traditional marketing is based on the existence of conscious homo economicus, which actually does not exist. Therefore the price of the product is not so important as it considered before. Actually, it is a challenge to the mankind. The same asDarwin's theory. But it is a fact. We are irrational and emotional. Sincewe perceive the world through five feelings at the same time, brands should stopappealing to logic and become more sensual. If companies appeal to a few feelings now, they should use all five [Wu T., 2011: 87].

Less is more. On the one hand, we have seen that the system of decision-making is not that sort as we previously thought and it's based primarily on emotions. On the other hand, for example, Mark Zuckerberg, who wears 10 identical gray T-shirts, says that he tries to make decisions only in case of vital necessity. He says: "When we spend too much energy on making trifling decisions, it prevents us from taking global ones". Why is it so?

It is interesting to follow different views on this issue of Malcolm Gladwell's speech at TED inspiration lectures in 2004 and the performance of Canadian psychologist Sheen Ayengar in 2010. The former said that one person had created 45 kinds of sauces for a company and thecompany made a profit of hundred milliondollars. The lattertold how Procter \& Gamble increased sales by $10 \%$ by cutting down a series of shampoo from 25 to 15 types.

This phenomenon is explained by Barry Schwartz, an expert in the field of choice. He says that a person illusory considers that the wider choice they have, the more freedom they get. However, consideration of alternative advantages, which were rejected, brings down the benefits of own choice and brings up a person's anxiety. People are tired of choice [Schwartz, 2004: 137].

So new approaches in marketing should include the possibility of not to chose. It's necessary to adjust the architecture of choice and make it more individual.

New marketing is marketing of stories. During the Soviet era we had lessons of political news. It was hell. The problem was that we did not tell stories, but only informed each other. Informing itself is boring. The story with its plot involves in its reality, it excites, shocks and captivates. We used to talk about storytelling, nowit'sstoryliving. Create and present stories, direct circumstances [Davenport T.H., Beck J.C, 2001: 34].

Marketing of closeness. In the"Person alone" essay,Erich Fromm reflects about loneliness of a man in the consumer society and theirinternal conflict between "tobe" and " to have". Fromm thoroughly considersthe phenomenon of human loneliness. He speaks about moral loneliness of a person, who can't correlate their own values with the values of the society, the person who has lost the connection with other people. He also speaks about the man's estrangement from himself. According to Fromm the reason of this estrangementis the lifestyle of the consumer society, where everything is focused on the production, sales and consumption, where a man turns into a product and estranges from his personality $[13,14]$.

To compensatethis estrangement, a man seeksplantom proximity in different external forms. This trend of illusory proximity exists in all spheres of our life. Sincewe differently perceive the same reality, and the language is a mediator, communication has also taken a 
course to convergence. The appearance of social networks, for example, makes closer not only friends, but also a company, a customer, a politician andhis audience. Communication changes its form. Itbecomes less formal and more friendly. Today the accent in communication should be placed on being on the same wavelength with the audience, being equal. Don't give any instructions, just help and advise [16, 17].

Conclusions. Thus, new marketing rules can be reduced to the following postulates:If you want somebody to learn about you - hide.Have you been found? Suggest participation. Participation "here and now". There is no sense, only emotions.And less is more.Become closer to each other by telling stories.Finally. Forget whatyou have been taught, what you have heard and what you have read. Experiment.

\section{References}

1. Zaltman G. (2003) How Customers Think: Essential Insightsint othe Mindofthe Market. Harvard Business School Press.

2. Kahneman D. (2011) Thinking, Fastand Slow.Farrar, Strausand Giroux.

3. Zaltman G. And ZaltmanL. (2008) Marketing Metaphoria: What Deep Metaphors Revealabou the Mindsof Consumers. Harvard Business School Press.

4. Трайндл A. (2017) Нейромаркетинг: визуализация эмоций [Neuromarketing: visualizationofemotions]. М. : Альпина Бизнес Букс.

5. Линдстром M. (2012) Виуоlogy: увлекательное путешествие в мозг современного потреби теля [Truthand Liesabout Why We Buy]. M. : Альпина Бизнес Букс.

6. Д. Льюис. (2015) Нейромаркетинг. Как проникнуть в мозг покупа теля [The Brain Sell: When Science MeetsS hopping]. М. : МИФ./

7. Kahneman D., Tversky A. (2000) Choices, Valuesand Frames. NewYork: Cambridge UniversityP ress.

8. Goldhaber M. (2011) Principlesof the neweconomy.

9. Брюс Худ. (2015) Иллюзия "Я" илиигры, в которые играет с нами мозг [The SelfIllusion: Why Thereis NoYou Inside Your Head]. М. : Эксмо.

10. Lanham R. (2006) Th eeconomic sofattention/ Style and substanceintheageo finformation. Chicago.

11. Kahneman D., Krueger A., Schkade D., Schwarz N., Stone A. (2006). Wouldyoubehappierifyouwerericher? A focusingillusion . Science.

12. Schwartz B. (2004) The Paradoxof Choice - Why MoreIsLess. Harper Perennial.

13. Фромм Э . «Человек одинок». http://nemaloknig.info/book-170791.html

14. Особенности массовой культуры: Эрнест ван денХааг об отчуждении и стандартизации [Features of mass culture: Ernest van den Haag about alienation and standardization] <http://monocler.ru/ryinok-massovoy-kulturyi/>

15. Льюис Д. (2016) Нейромаркетинг в действии [Neuromarketing in action]. М.: МИФ

16. Industrial strategymusthelp UK «creativeindustries» 〈www.bbc.com/news/business39604320>

17. Почепиов $Г$. «Писсуар Дюшана, или искусство как медиакоммуникация» [Duchamp's pissoiror artasa media communication] <psyfactor.org/lib/mediacommunication-11.htm>

18. Wu T. (2011) The Maste rSwitch. The Rise and Fallof Information Empires. NewYork.

19. Davenport T. H. ,Beck J. C. (2001). The Attention Economy: Understanding the New Currencyof Business. Boston. 